\title{
Unions and the Quality of Work Life
}

\section{Robert Wechsler}

\author{
Transport Workers Union of America
}

Most American workers and their trade unions are being confronted at the bargaining table with employer demands for more productivity. In their rush to gain a competitive edge and shore up profits, managements have selectively embraced Japanese business techniques including the use of Quality Circles (QC). These labor management problem-solving committees are probably the most common form of the Quality of Work Life (QWL) experiment included in contract packages. Despite the stated productivity objectives of QC, many employers have introduced them unilaterally or in non-union circumstances in order to undercut union power or to defeat organizing drives. There is no shortage of controversy on the subject.

The George Meany Center for Labor Studies, along with the Institute of Labor and Industrial Relations at the University of Michigan and Wayne State University presented a timely program on "Unions and Quality of Work Life" from February 8-10, 1982. In attendance were about 50 participants including representatives from unions with established QWL programs. The exchange between conferees and with speakers was spirited and manifested a healthy degree of caution.

Jerome Rosow, President of Work in America, Inc., provided an introduction to QWL programs. He outlined the major ones in existence, the pros and cons of establishing them, and the resistance that both unions and managements put up against such projects. He stressed that the programs can only be successful if both sides overcome the adversarial nature of collective bargaining and establish a cooperative relationship in these committees, certainly a tall order. QWL programs, according to Rosow, represent "the most promising opportunity for strengthening unions."

Hy Kornbluh, Director of the Labor Studies Center at the University of Michigan, analyzed the various forms of worker participation plans in America, Europe, and Japan. He extended the definition of QWL to include many of the participation schemes which enhance workplace democracy. Arthur Shostack, of Drexel University, placed the QWL programs in a historical context. He saw the possibility of a change in management styles from the current bottom-line pragmatism to a self-directed work ethic characterized by cooperation and, perhaps, codetermination. The change, he suggested, can come from a workforce which increasingly identifies worker participation issues as important. He cautioned unions 
about involving themselves in quick-fix QWL programs, but also advocated that they become bolder in identifying with change. Woody Ginsburg, Director of Research and Public Policy at the Center for Community Change, provided an economic framework with which to examine QWL issues. An evening of films presented by the University of Michigan's John Beck rounded out this section of the program.

The remainder of the conference was given over to case studies of QWL programs. Elvin Hendricks, United Auto Workers' Coordinator of Special Projects, outlined the U.A.W.-Ford Employee Involvement (EI) project. The program was established by contract in 1973 and revised in 1979. According to Hendricks, EI has eliminated many of the shop-floor grievances without compromising the grievance procedure. The greatest problem with EI has been middle managers' fears that the committee would encroach upon their power.

Richard Davis. Director of the Steelworkers' New Member Department, described how the financially-troubled steel companies introduced QWL programs ostensibly to improve quality and productivity. The national agreements with the union established clear guidelines for Labor-Management Participation Committees. As management and union worked out particulars at local sites, the QWL structure slowly evolved. Davis claimed a 75 percent acceptance rate of committeeproposed solutions to production problems. He also saw the process as useful for collecting contract data and involving new members in union activities.

The newly-established Communications Workers of America program, outlined by Charles Heckscher, is a highly centralized venture demanding a fulltime staff for implementing and servicing it. William Batt, Department of Labor, and Linda Lampkin, Research Director of American Federation of State, County, and Municipal Employees. spoke about some of the different pressures on public employee unions which affect QWL issues. Lampkin described the problem of bargaining on both an administrative level and a political one; the lack of bargaining rights for public employees in many states; and the problematic nature of measuring white collar productivity.

Stanley Wisniewski, Research Economist for the International Association of Machinists, reported on his union's cautious approach to QWL. The Machinist's current policy is that the lodge must have clear guidelines for participation. There must be an initial agreement over certain preconditions such as no layoff provisions and gain-sharing, and a statement as to how any financial savings would be used.

An international panel was also assembled to give the conference some additional points of reference. The West German approach to QWL and codetermination was analyzed by Labor Attaché Fritz Hauser. Peter Carr, Labour Counsellor from the U.K., outlined the Trades Union Congress' recommendations for participation in any QWL program by a member union. Similar to some of the American agreements, these guidelines mandated: no contravention of the existing grievance procedure; sharing of all productivity improvements; no job loss; and no infringement on the jurisdiction of other committees or organizations. He suggested that union participation should be used to widen the scope of QWL to include some of 
the critical work environment issues such as the impact of technological change on the workplace. Joji Arai, Manager of the Japan Productivity Center, reported that ten million Japanese workers participate in Quality Circles and QWL programs. His claims for the extensive success of QWL and labor-management cooperation appeared somewhat one-sided and were challenged by the audience.

The final presentations were made by Sam Camens of the Steelworkers and the participants themselves. Camens placed the issue of worker participation in a political as well as economic context, and spoke of QWL programs as only the first step in increasing workplace democracy.

The participants, in evaluating the conference, fell into three camps. A small group of conferees suggested that the QWL programs were the cutting edge of a movement to introduce democracy into the workplace. A majority of the group expressed interest in the concept of worker participation but had reservations about the effect of such programs on the power of the union at the worksite. Serious questions were also raised about the limitations placed on the scope of QWL discussions. Lastly, a small group of participants made clear their opposition to any QWL schemes, finding them too divisive to the interests of the union and their members. 